\title{
PSYCHOLOGICAL REPERCUSSIONS RELATED TO BRACHYTHERAPY TREATMENT IN WOMEN WITH GYNECOLOGICAL CANCER: ANALYSIS OF PRODUCTION FROM 1987 TO 2007
}

\author{
Gisele Curi de Barros $^{1}$
} Renata Curi Labate ${ }^{2}$

\begin{abstract}
Barros GC, Labate RC. Psychological repercussions related to brachytherapy treatment in women with gynecological cancer: analysis of production from 1987 to 2007. Rev Latino-am Enfermagem 2008 novembrodezembro; 16(6):1049-53.

One of the radiotherapeutic modalities for gynecological cancer treatment is brachytherapy, characterized by the placement of radioactive materials near the tumor. This treatment can bring side effects for patients. Due to the emotional issues involved, the objective of this research was to apprehend studies about psychological repercussions related to brachytherapy treatment in women with gynecological cancer, through a literature review. The results revealed an embryionic production, with only one study produced in Brazil. A higher concentration of studies was found in the Nursing area. Research focused on psychosocial repercussions, attempting to understand the patients' experiences before, during and after treatment, evidencing physical and psychological consequences that affect their quality of life. It is important to consider the expansion of this production through psychological research that furthers the comprehension about the experience of women submitted to brachytherapy.
\end{abstract}

DESCRIPTORS: brachytherapy; psychology; review literature as topic

\section{REPERCUSIONES PSICOLÓGICAS RELACIONADAS AL TRATAMIENTO DE BRAQUITERAPIA EN MUJERES CON CÁNCER GINECOLÓGICO: UN ANÁLISIS DE LA PRODUCCIÓN DE 1987 A 2007}

Una de las modalidades de radioterapia para el tratamiento del cáncer ginecológico es la braquiterapia, caracterizada por la colocación de materiales radioactivos junto al tumor. Esta terapéutica puede traer efectos colaterales a los pacientes. Pensando en las cuestiones emocionales, este trabajo tuvo como objetivo, a través de la revisión de la literatura, revisar los estudios que se refiriesen a las repercusiones psicológicas relacionadas al tratamiento de braquiterapia en mujeres con cáncer ginecológico. Los resultados revelaron una producción embrionaria, con apenas un trabajo producido en Brasil. Hubo una mayor concentración de estudios en el área de Enfermería. Los trabajos se centraron en las repercusiones psicosociales, buscando comprender la experiencia de las pacientes antes, durante, y después del término de la aplicación del tratamiento, lo que colocó en evidencia consecuencias físicas y psicológicas que afectan la calidad de vida. Es importante pensar en un incremento de esta producción con investigaciones psicológicas que profundicen la comprensión de la vivencia de mujeres sometidas a la braquiterapia.

DESCRIPTORES: braquiterapia; psicología; literatura de revisión como asunto

\section{REPERCUSSÕES PSICOLÓGICAS RELACIONADAS AO TRATAMENTO DE BRAQUITERAPIA EM MULHERES COM CÂNCER GINECOLÓGICO: ANÁLISE DA PRODUÇÃO DE 1987 A 2007}

Uma das modalidades radioterápicas para tratamento do câncer ginecológico é a braquiterapia, caracterizada pela colocação de materiais radioativos junto ao tumor. Essa terapêutica pode trazer efeitos colaterais às pacientes. Pensando nas questões emocionais, este trabalho objetivou, através de revisão de literatura, apreender estudos que se referissem a repercussões psicológicas relacionadas ao tratamento de braquiterapia em mulheres com câncer ginecológico. Os resultados revelaram produção embrionária, com apenas um trabalho produzido no Brasil. Houve maior concentração de estudos na área de enfermagem. Os trabalhos centraram-se nas repercussões psicossociais, buscando compreender a experiência das pacientes antes da aplicação, durante essa, e após o término do tratamento, evidenciando conseqüências físicas e psicológicas afetando a qualidade de vida. É importante pensar no incremento dessa produção com pesquisas psicológicas que aprofundem a compreensão da vivência de mulheres submetidas à braquiterapia.

DESCRITORES: braquiterapia; psicologia; literatura de revisão como assunto

University of Sao Paulo at Ribeirao Preto College of Nursing, WHO Collaborating Centre for Nursing Research Development, Brazil

${ }^{1}$ Psychologist, Master's student, e-mail: gicuri2@hotmail.com. ${ }^{2}$ RN, Faculty, e-mail: labatere@eerp.usp.br. 


\section{INTRODUCTION}

Brachytherapy is a modality of radiotherapy that is characterized by the placement of radioactive materials in contact with the tumor, used for the first time almost one hundred years ago. An intracavitary system can be used for its application, i.e. the radioactive source remains within a body cavity. As years went by, this type of therapy enjoyed new advances, with the development of methods for the calculation of doses, new radioactive materials and different application techniques, such as the use of computers, computerized axial tomography and magnetic resonance imaging, improving the accuracy of brachytherapy with a better delimitation of the normal and neoplasic tissues ${ }^{(1)}$.

Brachytherapy can be used as a therapeutic modality for several types of cancers, including gynecologic tumors, with a considerable possibility of satisfactory results according to the tumor stage. Although there are a few side effects, which may vary among women, these generally comprise transitory side effects, such as nausea, vomiting, indisposition and variable-intensity anorexia, along with abdominal cramps, diarrhea, dysuria and polacyuria, and late side effects or radiation sequels that are permanent, such as rectitis and actinic cystitis, with colitis and subcutaneous fibrosis occurring less frequently ${ }^{(2)}$.

Considering the repercussions that this treatment can bring to the lives of patients, it is important to reflect about psychological issues that could somehow be related to the execution of brachytherapy in patients with gynecological cancer, and about the development of research studies about this topic.

As such, the objective of this study was to perform a systematized review of the literature, seeking to apprehend studies on psychological repercussions related to brachytherapy treatment in women with gynecological cancer, aiming at obtaining a more concrete panorama of the Brazilian and international production about the aforementioned theme.

\section{STRATEGIES FOR SEEKING MATERIALS}

At first, it was necessary to define the keywords that would be more adequate to the proposed objective. The terms brachytherapy and psychology were then chosen. Five online databases were queried: MedLine, PsycInfo, Web of Science, LILACS and Index Psi.

For the search of material, the aforementioned keywords were cross-referenced. The articles found were submitted to the following inclusion criteria: having been published in the 1987-2007 period; the type of cancer being in the woman's genital region; the type of treatment being brachytherapy, at either high or low dose rates; referring to psychological issues of the patients involved in the brachytherapy treatment.

The material was primarily selected by reading the abstracts of the articles, considering the established inclusion criteria. When an abstract did not provide enough information for the acceptance or rejection of the study, it was necessary to seek this in the full text of the article, allowing for better discrimination regarding the pertinence of the study for this literature review.

With the conclusion of the selection of abstracts, the full texts were then sought out. This was executed by consulting the journals available at the Central Library of the USP-Ribeirão Preto Campus; downloading journals that were not available at this library, but accessible online; e-mailing the author or the journal; and finally, through the Bibliographic Commuting Program (COMUT) in this library, which, in partnership with the libraries of other colleges, makes it possible to seek journals that are not available in its own inventory.

The articles were read in their full version, and analyzed according to the following dimensions: type of scientific production; year of publication; concentration area and country of origin; themes studied; goals; methodological resources employed; main results obtained.

\section{RESULTS AND DISCUSSION}

Articles were found only in MedLine out of five databases consulted. 107 references were found with the cross-referencing of the keywords, which needed to be selected according to the inclusion criteria. Therefore, the effectively collected material totaled eight articles, i.e. less than $10 \%$ of the total references. This discrepancy is explained because most studies are about other types of cancer prostate cancer in particular - and one of the inclusion 
criteria had established that the tumor had to be located in the women's genital region.

It is worth noting that, among the selected studies, some did not refer only to the brachytherapy treatment, but also to other types of treatment, such as surgery, external radiotherapy and chemotherapy ${ }^{(3-4)}$. Besides, there were also articles specifically about brachytherapy, but the cancer was not only the gynecological type, with other tumors being included ${ }^{(5-7)}$. Thus, it can be said that, despite being about more than one treatment modality and/ or different types of cancer, these studies at least contemplated, at the same time, brachytherapy and gynecological cancer, indicating that the preestablished inclusion criteria were respected.

Having the total amount of references found by the search, regardless of the specific type of tumor, it can be said that a considerable amount of studies have been produced which somehow involve the brachytherapy treatment and psychological issues. However, these studies were contemplated only by MedLine, revealing a concentration of this production in the medical area. Considering the specificity of the tumor, i.e. gynecological cancer, the amount of articles decreased considerably, indicating a production that is much more restricted to the women's healthcare area.

Regarding the first dimension of analysis, all the articles apprehended come from original research studies, a very important characteristic. Since the study field seems to be embryonic, such production has only advantages for building the scientific knowledge with this approach. It is not surprising that there are no literature review articles because, if the field is still being built, it is first expected to have a relative production, so that an appreciation of the type and quality of this production can be performed later, even as a guideline for future research.

About the second dimension of analysis, i.e. the year of publication, the articles are mostly recent, with a higher concentration of studies in the past eight years. Even if the period selected covered 1987 to 2007, i.e. a twenty-year span, the studies about brachytherapy treatment for gynecological cancer, and which also make reference to psychological repercussion, date from 1991 onwards $^{(5)}$.

The obtained production was predominantly international, with only one study produced in Brazil ${ }^{(8)}$. Regarding the third dimension of analysis, the studies were performed in European countries, and also the
United States, Canada, Australia and Russia. The sample is very small, which makes generalizations impossible, but it can be noticed that no country is predominant in this type of research. However, about the area of concentration, six studies were produced by Nursing professionals and published in Nursing journals ${ }^{(5-10)}$.

This fact is worth noting, since a large amount of the studies was performed by researchers of the nursing area, whereas only one study was linked to a Psychology Department ${ }^{(4)}$. It was expected that most articles would be developed by professionals from the Psychology field, since one of the keywords was "psychology". However, some hypotheses were formulated about this issue. As mentioned before, this production is concentrated in the medical area. Brachytherapy, being a medical treatment modality, can probably be better known by professionals working directly with it - usually nurses, physicians, physicists and radiology technicians. This approximation with the treatment can raise questions in the professionals themselves, which drives them to develop studies. Several professionals of the Nursing area have performed studies that seek to cover psychological issues, because such questions tend to surface in their daily "hands-on" care for the patients. There may be a need to understand more about the patients' feelings, perceptions and difficulties about the treatment they are submitted to.

Another hypothesis to be considered is the fact that the work of the psychologist with cancer patients, specifically in the hospital context, is a recent phenomenon. The so-called Psycho-Oncology is a field of study and interventions that started in the 1970 s and 1980s, becoming better established by the end of the $20^{\text {th }}$ century. This specialty benefited greatly from the contribution of research developed by nursing professionals, who combined their perceptions in their daily contact with the patients with psychological research methodologies ${ }^{(11)}$.

About the fourth dimension of analysis, the themes studied by the researchers were: need for information about cancer patients receiving brachytherapy with low dosage rates ${ }^{(5)}$; the experience of gynecological cancer patients submitted to brachytherapy treatment with low dosage $\operatorname{rates}^{(8-10)}$; side effects and quality of life in patients submitted to cancer treatment, particularly the gynecological type ${ }^{(3-}$ $4,6)$, especially one of the articles that referred more specifically to sexual adjustment after gynecological 
cancer treatment ${ }^{(4)}$. One of the studies sought to clarify problems in the nurse-patient interaction during the application of brachytherapy with low dosage rates, by using a new clinical research tool for nursing care for cancer patients, which is the continuous video recording $^{(7)}$.

The studies related to the experience of women with gynecological cancer submitted to brachytherapy, overall, aimed to understand this experience. More specifically, the Brazilian research sought to identify the difficulties and problems experienced by patients submitted to cesium-casting (brachytherapy) treatment. Also, it provided the nurses with support to better understand this experience in their activities as supporting elements during healthcare ${ }^{(8)}$. The European research aimed to explore the experience of the patients in the different moments of their treatment, i.e. before, during and after the application of brachytherapy ${ }^{(10)}$.

The articles about the side effects and quality of life of the patients submitted to cancer treatment had different objectives: the description of side effects and changes in quality of life for patients receiving brachytherapy with high dosage rates for bronchial and gynecological cancer $^{(6)}$; the investigation of quality of life in clinical remission patients after the treatment for gynecological cancer (which involved several modalities, such as surgery, chemotherapy, external radiotherapy and brachytherapy), seeking to apprehend whether there would be differences in quality of life related to the treatment modality, and whether the side effects would be related to time ${ }^{(3)}$; the investigation of psycho-sexual adjustment after treatment in women treated for uterine and endometrial cancer, who received several treatment modalities (surgery, external radiotherapy, brachytherapy), as well as the impact of the posttreatment sexual function on general quality of life, and the psycho-sexual necessities of the women and their partners ${ }^{(4)}$.

The objectives of the other studies analyzed were: determining the types of information necessities of cancer patients who received brachytherapy, the amount of information received and the participation in medical healthcare desired by the patients, and the relations between information needs and the following selected variables: preference for participation, age, education, stage of the disease and emotional state ${ }^{(5)}$; measuring how long nursing care lasts for patients with gynecological and anal cancer exposed to brachytherapy with low dosage rates, as well as investigating and describing the interaction and communication between patients and nurses during internal radiotherapy treatment ${ }^{(7)}$.

As for the sixth dimension of analysis, the methodological strategy used, there was a nearly equal amount of quantitative and qualitative approaches. The latter was used in the study linked with a Psychology Department ${ }^{(4)}$ and in articles on the experience of gynecological cancer patients submitted to brachytherapy treatment. Even then, one of the studies had a quanti-qualitative approach ${ }^{(10)}$. Another article blended both approaches, using statistical analysis to evaluate the length of brachytherapy treatment, and quantitative analysis to apprehend nurse-patient interaction during this treatment ${ }^{(7)}$. The others used quantitative approaches, with the application of questionnaires and other instruments ${ }^{(3,5-6)}$.

The seventh dimension of analysis found that the studies converged in several aspects of their results. The importance of providing information prior to the application of brachytherapy, a resource that can aid in coping with this type of treatment, was reported by most articles ${ }^{(4-5,8-10)}$. However, the information and orientation received did not always prepare the women sufficiently for the type of situation they were about to experience; besides, even when the patients felt well-informed about their treatment, there were still many concerns and anxiety before its execution. This can be explained because brachytherapy is a stressful event for the patients due to characteristics of this treatment modality, which imposes several challenges for the women.

When the choice of treatment is brachytherapy with low dosage rates, the patients can remain up to four days with the radioactive implant, and this entails several consequences for the women submitted to this situation. Some researchers noted the difficulties the patients felt, regarding being restricted to bed and the impossibility of moving the pelvic region, so that the device would not be displaced; about pain, especially back aches, pain due to immobility and pain when the implant was removed; treatment duration; isolation; fatigue and difficulty to eat. Analgesic medication was administered for pain reduction and control. In the face of the treatment conditions and the long time of treatment, the women sought coping strategies, such as watching television, 
reading, listening to music, reflecting about their own life, etc ${ }^{(8-10)}$.

The brachytherapy treatment brought several side effects for the patients, such as fatigue, changes in urinary frequency and dysuria ${ }^{(6)}$; also, problems like diarrhea were associated to this type of radiotherapy ${ }^{(3,6)}$. According to the authors, the effects were even more intense immediately after treatment; however, some problems persisted over time, even after the end of the treatment.

As for sexual adjustment after treatment for gynecological cancer, women submitted to joint treatments (surgery, external radiotherapy and brachytherapy) had higher levels of sexual dysfunction. Reduced lubrication, loss of sensation, reduced libido and shortening of the vagina were the physical dysfunctions most often mentioned by the irradiated women ${ }^{(4)}$.

Considering that the brachytherapy treatment brings difficulties to the women, either before, during, shortly after and long after its administration, most studies highlighted the importance of the professionals who deliver care to the patients knowing about these implications, particularly nurses. The study about nurse-patient interaction during the application of brachytherapy showed that, even though the professionals had enough time to provide attention and care to the patients, this time was under-utilized, and the communication with the patients was centered on physical contact $^{(7)}$.

\section{FINAL CONSIDERATIONS}

According to what could be apprehended from the articles, there seems to be an overall concentration of studies on the psychosocial issues related to brachytherapy. The articles focused on comprehending the experiences of women with this type of radiotherapy, as well as its consequences for the patients' quality of life. Brachytherapy and its side effects pose a series of physical and psychological difficulties, and it is important that the healthcare professionals understand these difficulties better, so that they can aid the women to cope with this treatment modality. However, as noted before, there were almost no articles written by researchers in the Psychology field. Thus, it is relevant to think about increasing the existent production with psychological studies that will further research about the experiences of patients with this treatment, using an approach that considers not only the conscious aspects, but also unconscious issues that may be related to the application of brachytherapy, using the psychoanalytical reference framework as a background.

\section{REFERENCES}

1. Pinto ACLC. A história da braquiterapia. In: Pinto ACLC, Pereira $A J$, Pena $A B C$, Maltez Filho A, Galante $C$, Vigna Filho ED et al. A radioterapia no Brasil. Curitiba (PR): Liga Paranaense de Combate ao Câncer; 1995. p. 31-3.

2. Petitto JV. Câncer dos órgãos genitais: tratamento radioterápico. In: Halbe HW. Tratado de Ginecologia, v.3. $3^{\text {a }}$ ed. São Paulo: Roca; 2000. p. 2343-53.

3. Carlsson M, Strang P, Bjürstrom C. Treatment modality affects long-term quality of life in gynaecological cancer. Anticancer Res 2000; 20 (1B): 563-8.

4. Juraskova I, Butow P, Robertson R, Sharpe L, Mcleod C, Hacker N. Post-treatment sexual adjustment following cervical and endometrial cancer: a qualitative insight. Psychooncology 2003; 12 (3): 267-79.

5. Brandt B. Informational needs and selected variables in patients receiving brachytherapy. Oncol Nurs Forum 1991;
18 (7): 1221-7; discussion 1227-9.

6. Fieler VK. Side effects and quality of life in patients receiving high-dose rate brachytherapy. Oncol Nurs Forum 1997; 24 (3): 545-53.

7. Andersen C, Adamsen L. Continuous video recording: a new clinical research tool for studying the nursing care of cancer patients. J Adv Nurs 2001; 35(2): 257-67.

8. Clapis MJ, Mamede MV. Vivências de mulheres submetidas à cesiomoldagem. Rev Latino-am Enfermagem 1996; 4(2): 131-46.

9. Velji K, Fitch M. The experience of women receiving brachytherapy for gynecologic cancer. Oncol Nurs Forum 2001; 28(4): 743-51.

10. Warnock C. Patient's experiences of intracavity brachytherapy treatment for gynaecological cancer. European J Oncol Nurs 2005; 9: 44-55.

11. Holland JC. Psychological care of patients: PsychoOncology's contribution. J Clin Oncol 2003; 21(23): 253-65. 